\title{
Geometrical Proportion in the Sixteenth Century: Methods and Constraints
}

\author{
José Calvo-López ${ }^{1}$ (D) Macarena Salcedo-Galera ${ }^{1}$
}

\begin{abstract}
Common conceptions about Gothic and Renaissance architectural proportion systems contrast the mediaeval geometrical methods with the arithmetical, rational ones of the Renaissance. In this paper, the authors analyze the geometrical proportion systems in Chapter $\mathrm{V}$ of Compendio de Arquitectura y simetría de los templos, generally attributed to the sixteenth-century Spanish architect Rodrigo Gil de Hontañón. This shows that geometrical proportioning system of the Compendio generally leads to rational proportions. However, on some occasions, irrational proportions arise from the geometrical properties of the figures used in the layout of the churches, or from deliberate choices of the author, with a remarkable disregard for the notions of commensurable or incommensurable dimensions. This is consistent with the notion, put forward by Shelby, of constructive geometry. Medieval design methods were based on a compass and ruler geometry, with no concern for rational and irrational proportions.
\end{abstract}

Keywords Proportional systems - Spanish Renaissance architecture · Rodrigo Gil de Hontañón - Compendio de arquitectura y simetría de los templos . Geometrical systems · Arithmetical systems · Rationals · Irrationals · Commensurable ratios $\cdot$ Incommensurable ratios

José Calvo-López

jose.calvo@upct.es

Macarena Salcedo-Galera

macarena.salcedo@upct.es

1 Universidad Politécnica de Cartagena, Paseo Alfonso XIII, 50, 30203 Cartagena, Spain 


\section{Introduction}

Rudolf Wittkower, in his classic Architectural Principles in the Age of Humanism (1949), set the arithmetical, rational, commensurable systems of proportion of Renaissance architecture in opposition to the geometrical, irrational and incommensurable practices of the Middle Ages. However, he warned that Renaissance graphical methods with an apparent geometrical basis could lead to rational proportions, citing an example taken from Serlio (1545: 23r). A few years later, Otto von Simson (1956) argued that rational systems of proportion were frequently used in the Gothic period. In order to gauge the use of geometrical and arithmetical proportion systems in the first half of the sixteenth century, we shall analyze the proportion systems for churches included in Compendio de Arquitectura y Simetría de los templos, that is, "Summary of Architecture and Temple Symmetry" (Fig. 1). This manuscript, written by Simón García (1681), states in its introduction that most of its content derives from Rodrigo Gil de Hontañón, the main designer of the cathedrals of Segovia and Salamanca in the mid-sixteenth century.

Marcelino Menéndez Pelayo (1883-1889: 2, 377, note 2) identified Rodrigo's contribution with the first six chapters of the treatise. This stance has been followed by most scholars who have dealt with the manuscript, in light of the strong difference between these chapters, which deal with traditional church plans and rib vaults, and the rest of the manuscript, which focuses on the orders and classical plane geometry, although there are some contradictions and disagreements in the details (see Camón 1941: 301, 305; Gómez-Moreno 1949: 11-12; Hoag 1958: 406; Bonet 1991: 14-15; Sanabria 1982: 282). Further, Hoag (1958: 410) placed the start of the planning of Rodrigo's contribution in the early 1560s, while Sergio Luis Sanabria (1984: 149-150) argued for an earlier date, between 1544 and 1554.

Chapter V of the Compendio, traditionally ascribed to Rodrigo Gil as mentioned, includes four geometrical schemes for the general layout of churches of different sizes. These diagrams have been analyzed by Chanfón (1991) and Sanabria (1984: 107-110); however, these authors do not examine the drawings exhaustively and do not furnish complete proofs for their assertions. Rodríguez et al. (2012) have carried out a thorough analysis of the first drawing, leaving aside the other three; their presentation does not show clearly the proportions of the nave bays. Thus, it is worthwhile to present here a detailed geometrical study of all four drawings.

\section{The Double-Aisle Church in fols. $11 \mathrm{v}-12 \mathrm{v}$ of the Compendio}

The first drawing, found on fol. 12r of the Compendio, represents a double-aisle church, with a semicircular ambulatory (Figs. 2, 3).

The plan resembles the cathedral of Segovia, where Rodrigo Gil acted as master mason (Hoag 1958: 160-170, 345-355; Casaseca 1988: 85-95). The whole temple is enclosed in a square. In order to determine the total width of the church, the author places points $\mathrm{G}$ and $\mathrm{B}$ at the middle of two sides of this square. The intersection of BG with the diagonal of the square, located at X, determines the width of the church. Next, he draws lines from points $\mathrm{R}$ and $\mathrm{O}$, which divide the sides of the square into fourths, to 


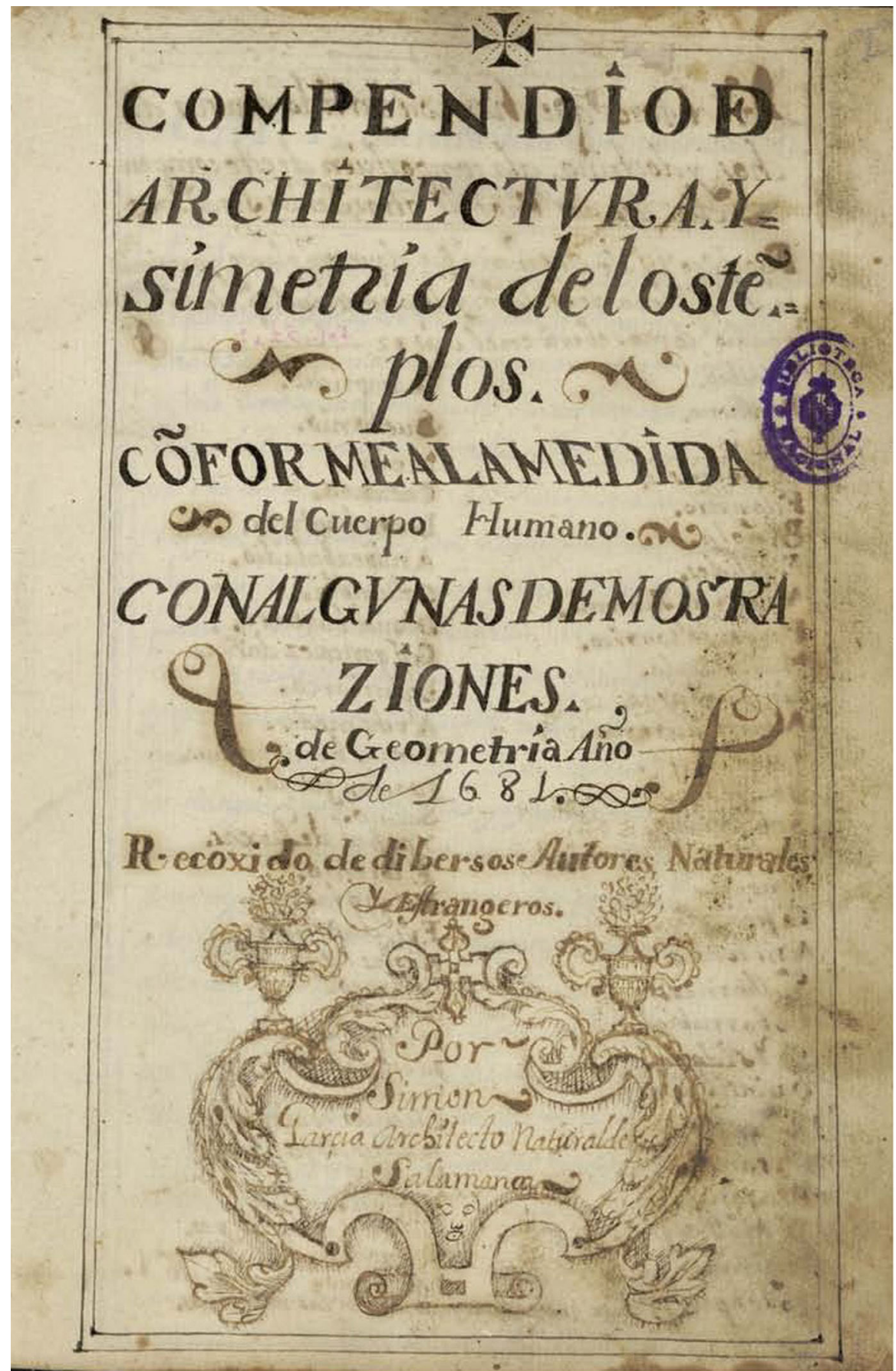

Fig. 1 First page of Compendio de arquitectura y simetría de los templos, by Simón García, 1681, with portions taken from Rodrigo Gil de Hontañón, c. 1550. Biblioteca Nacional de España, MSS/8884. The image is property of Biblioteca Nacional de España 


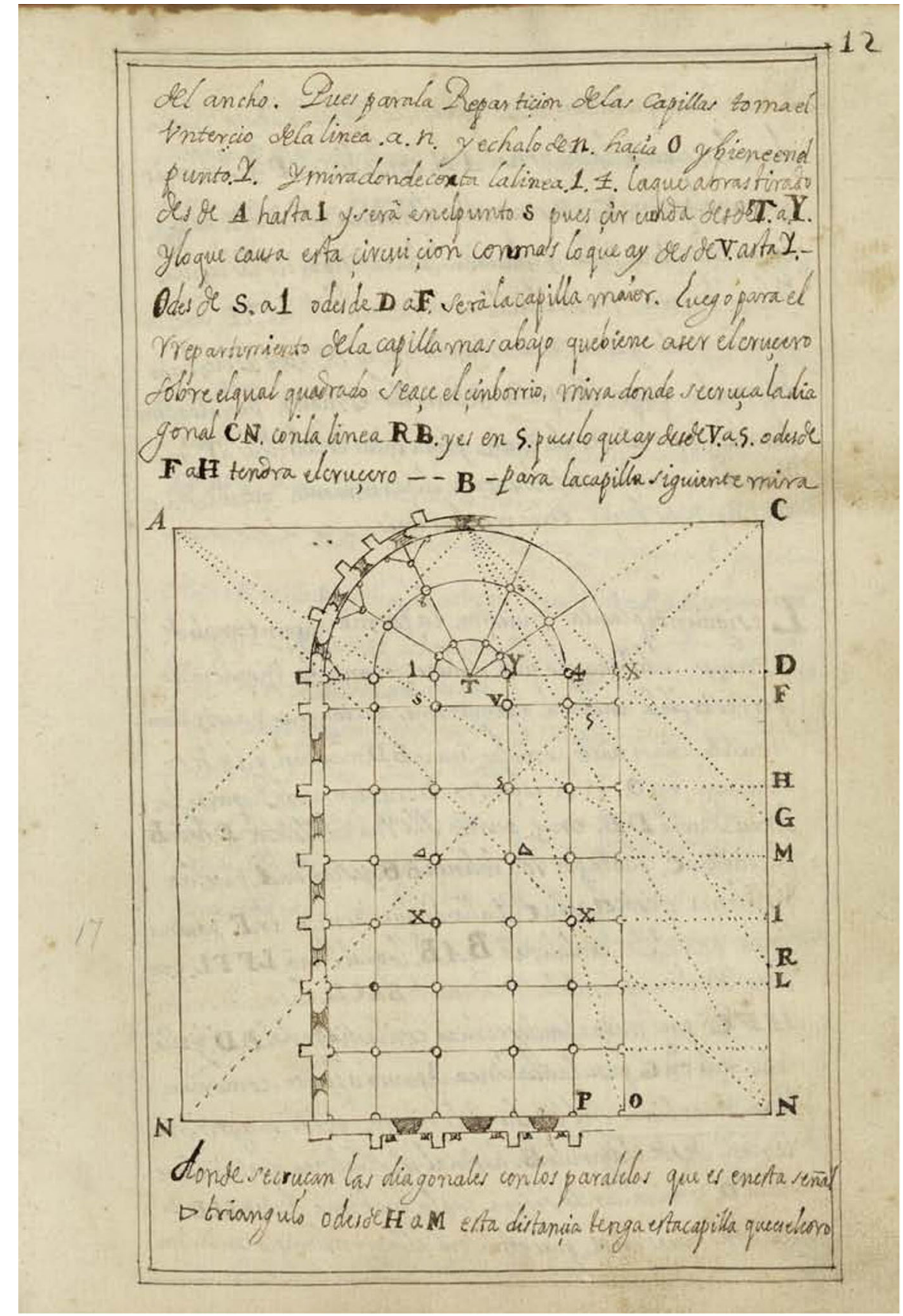

Fig. 2 Church with double aisles in fol. $12 \mathrm{r}$ of Compendio de arquitectura y simetría de los templos. Biblioteca Nacional de España, MSS/8884. The image is property of Biblioteca Nacional de España. Reproduced by permission 


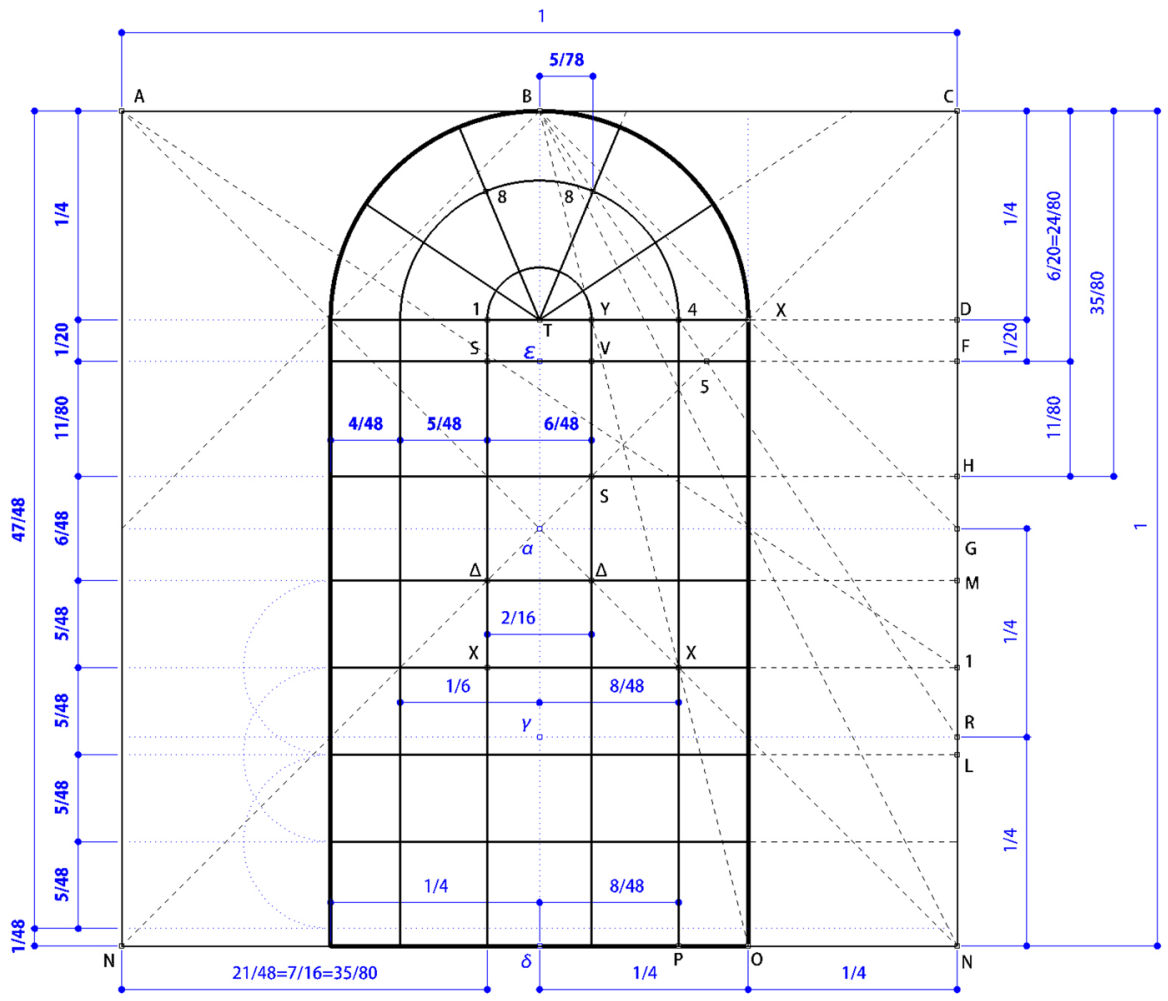

Fig. 3 Church with double aisles in fol. 12r of Compendio de arquitectura y simetría de los templos, $\mathrm{BNE}, \mathrm{MSS} / 8884$. Drawing by the authors

B. Points 4 and $Y$, located at the intersections of these lines with a parallel to the side of the square drawn by $\mathrm{X}$, determine the position of the arcades of the church, dividing the nave and the first and second aisles.

It is easy to see that $\mathrm{CX}$ is the diagonal of a square whose side equals $1 / 4$ of the larger enclosing square, and thus the total width of the church is $1 / 2$ the side of the enclosing square. Since the sanctuary is a semicircle, the proportion of the rest of the church is $3 / 2$ or sesquialtera, as stated by Chanfón (1991: 39). The rest of the procedure seems to lead to complex and irregular results. ${ }^{1}$ However, a detailed analysis shows different conclusions. For the sake of clarity, we will use the side of the enclosing square as a basic reference unit, $\mathrm{U}$. It is clear that BG is the diagonal of a small square, that the

\footnotetext{
1 Despite his interest in musical ratios, Chanfón [(1979) 1991, 39] does not mention the simple proportions between nave and aisle widths, nor those between bay depths. Rodríguez et al. (2012) state correctly that the proportion between the nave and the first and second aisles is $4 / 5 / 6$. However, they use an arbitrary dimension of 400 feet for the enclosing square; the manuscript does not mention such a dimension, nor in fact any dimension in the whole Chapter V, and Rodríguez et al. do not quote a source for this assumption. This leads Rodríguez et al. to compute the nave and aisle widths and the depths of the bays in feet, arriving at such measurements as 33.33 or 41.67 feet, which does not help to show the simple proportions of the design.
} 
sides of this small square equal $1 / 2$ of the sides of the larger square, and that the intersection of $\mathrm{BG}$ and $\mathrm{CN}$ is the centre of the smaller square. Thus XT, which represents $1 / 2$ the width of the church, equals $1 / 4$ of the basic unit.

In order to compute the combined width of half the nave and the first aisle, we can take into account that triangles BT4 and $\mathrm{B} \gamma \mathrm{R}$ are similar, and the former measures $1 / 3$ of the dimensions of the latter. Thus, T4, the combined width of half the nave and the first aisle, measures $1 / 3$ of $\mathrm{R} \gamma$, that is, $1 / 6$ of the basic unit. Similar triangles can also be used to measure the width of the nave. The dimensions of the small triangle BTY are $1 / 4$ of those of the larger triangle $\mathrm{B} \delta \mathrm{O}$; thus, TY, half the width of the nave, equals $1 / 4$ of $\delta \mathrm{O}$, that is, $1 / 16$ of the reference unit.

Unifying these measures through their least common multiple, we get $6 / 48$ of the basic unit for the width of the nave, $5 / 48$ for the first aisle and 4/48 for the second aisle. That is, an apparently capricious geometrical construction results in a neat series of simple arithmetical proportions, 4, 5, 6; even the proportion between nave and second aisle equals $2 / 3$, that is, a perfect fifth, diapente or proportio sesquialtera.

Bay lengths do not follow such a neat scheme. Point 5, placed at the intersection of the line drawn from point $\mathrm{B}$ to point $\mathrm{R}$ and the diagonal of the enclosing square, $\mathrm{NC}$, gives the division between the presbytery and the crossing. This is a typical trait of Spanish cathedrals and large churches; since the half-circle $1 Y$ is usually insufficient for the presbytery, while the choir is placed at the other side of the crossing, a short rectangle is added in order to enlarge the sanctuary. Next, points $S$, $\Delta$, and $\mathrm{X}$, located at the intersections of the main diagonals $\mathrm{CN}$ and $\mathrm{AN}$ with the arcades, give the depths of the crossing, first and second bays of the nave. According to the text, the depths of subsequent bays equal that of the second one.

The depth of the shallow rectangle added to the presbytery can again be computed using similar triangles. Considering that the proportion between both catheti of triangles $\mathrm{B} \varepsilon 5$ and $\mathrm{B} \gamma \mathrm{R}$ is $2 / 3$, and $\mathrm{C} 5$ is the diagonal of a square, it can be proved that $\mathrm{T} \varepsilon$ equals U/20 (see Appendix "Depth of the shallow rectangle added to the presbytery"). The rest is simpler, although there are some surprises. The depth of the crossing, given by the intersection of the diagonal with the first arcade, equals $11 \mathrm{U} / 80$. Since the width of the nave is $U / 8$, the crossing is not square, departing from usual practice (see Appendix "Depth of the crossing"). In contrast, the first bay of the nave, which usually houses the choir in Spanish churches, is square; its depth, $\mathrm{S} \Delta$, is given by the intersections of the diagonals with the main arcades, at both sides of the nave. Thus, the depth of the first bay equals $1 / 8$ of the basic unit, that is, $6 U / 48$. The depth of the second bay is given by the intersection of the diagonal with the arcades, so it equals $5 U / 48$, the width of the first aisle; this depth is used also for the third, fourth and fifth bays. ${ }^{2}$

\footnotetext{
${ }^{2}$ Converting the dimensions given in feet by Rodriguez et al. (2012) into our basic unit, they coincide with our computations, except the last bays, which are explicitly corrected by Rodríguez et al., as explained in the next note. Sanabria (1984: 108) states that "Using numerous other constructions, a variety of bay lengths is obtained, proportioned on a ratio beginning from the choir of 2:7:6:5:5-1/3:5-1/ $3: 5-1 / 3$ ", without further explanation. It seems that the "choir" does not refer to the actual choir of the church in the Compendio, placed at the first bay of the nave, as usual in Spain, but rather to a portion of the sanctuary, the customary position of the choir in French and English cathedrals, or more precisely to the shallow presbytery extension. Thus, 7 should correspond to the crossing, 6 to the first nave bay, and so on. However, Sanabria's proportions do not match our own results, which are coincident with the measurements given by Rodríguez et al., except for the problematic last bays.
} 
There is another surprise. In the drawing, the aggregated depths of the ambulatory, the presbytery extension, the crossing and all five bays equal the length of the side of the enclosing square. However, when adding the numerical values of these depths, the result amounts to $47 / 48$ of this basic unit; that is, the total length of the church does not fill the enclosing square, in contradiction with the drawing. It is not easy to tell whether this inconsistency between text and drawing comes from the original text of the Compendio, or was introduced by Simón García or an intermediate copyist. Hopefully, future studies on the authorship of the manuscript, which are out of the scope of this paper, will shed some light on this puzzling issue. ${ }^{3}$

As a final stage, the author of the Compendio explains a peculiar method for the division of the ambulatory into five bays. One of the division points, 8 , is placed at the intersection of the line BR with the semicircle that divides the inner from the outer ambulatory. Then, the angle T84 is divided again into halves. Repeating the procedure at the other side of the church, the ambulatory is divided into five sections. As a result of bisection and axial symmetry, the first, second, fourth and fifth bays are equal in length; by contrast, nothing guarantees that the third, central section equals the other bays.

The position of the dividing point 8 can be computed today by writing the equations of line B4 and the semicircle that divides the inner and the outer ambulatory. Somewhat surprisingly, the coordinates of 8 are rational, namely $(5 / 78$, 2/13). Using this result, the magnitude of angle T84 can be determined as 1.176 radians or $67^{\circ} 22^{\prime} 47^{\prime \prime}$. The angular measure of the four outer bays of the ambulatory equal $1 / 2$ this value, that is, $33^{\circ} 41^{\prime} 24^{\prime \prime}$, while the central bay measures $45^{\circ} 14^{\prime} 25^{\prime \prime}$, appreciably larger than the side bays (see Appendix "Angular dimensions in the ambulatory"). The author of the Compendio mentions the retablo, or altarpiece, of the church in connection with this bay; this suggests that he is deliberately giving a larger span to the central bay.

\section{The Single-Aisle Church in fols. 12v-13r of the Compendio}

The second church in Chapter $\mathrm{V}$ features a single-aisle with a characteristic chamfered sanctuary, known in Spanish as ochavo (Figs. 4, 5).

First, the author instructs the reader to construct an auxiliary square BBDD, as in the preceding example, but this time the side of the square equals the width of the church, not its length; in this way, the square will enclose only the chancel, the crossing and the first bay, not the whole church. In this section of the paper, we shall use the side of this square, $\mathrm{U}$, as the basic reference unit.

After drawing the diagonals, the side of the square is again divided into four parts, so that a line can be drawn from point $\mathrm{C}$ to A. A crossing pier is placed at point $\mathrm{F}$, where this line meets the diagonal of the square. Repeating this operation four times, the original square is divided into nine unequal portions. The central one

\footnotetext{
3 Both Sanabria (1984: 108-109) and Rodríguez et al (2012) seem to adjust the length of the third, fourth and fifth bays, trying to compensate for this error. However, they do not consider the possibility that the error may originate elsewhere, for example in the sanctuary extension, the crossing or the first or second bays.
} 


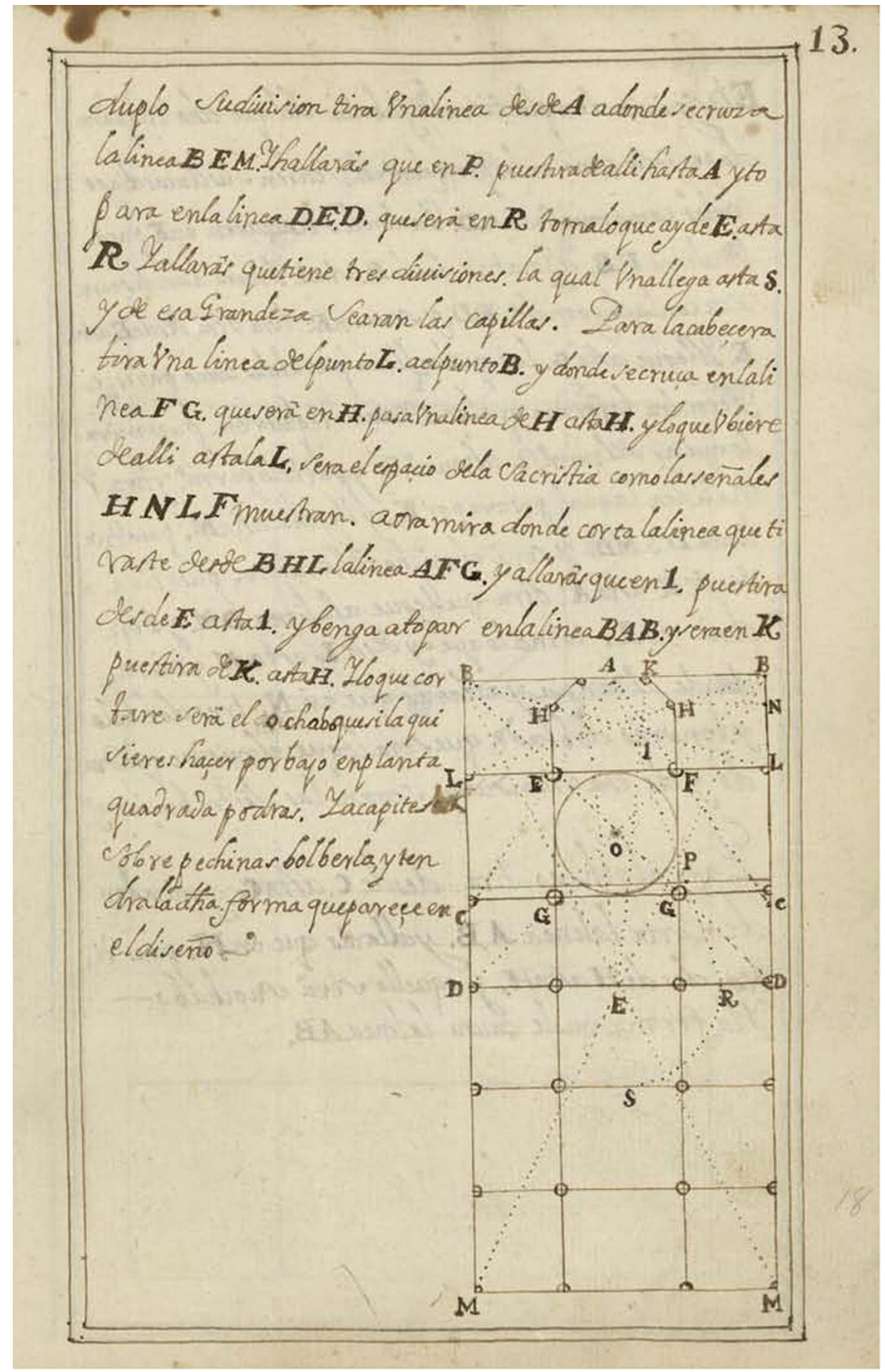

Fig. 4 Church with single aisles in fol. 13r of Compendio de arquitectura y simetría de los templos. Biblioteca Nacional de España, MSS/8884. The image is property of Biblioteca Nacional de España. Reproduced by permission

will furnish the crossing; the four lateral ones will be used as the sanctuary, transepts and first bay of the nave. As to the four corner sections, two will be used for the first bay of the aisles, another one will house the sacristy, and the fourth one will be left uncovered.

Once again, such apparently haphazard methods conceal rational, arithmetical proportions. Considering that $\mathrm{A} \alpha \mathrm{F}$ and $\mathrm{ABC}$ are similar triangles, the proportion between their catheti is $2 / 3$, and $\alpha B L F$ is a square, it can be proved that the width of the crossing and the nave equals $2 / 5$ of the width of the church (see Appendix "Width of 


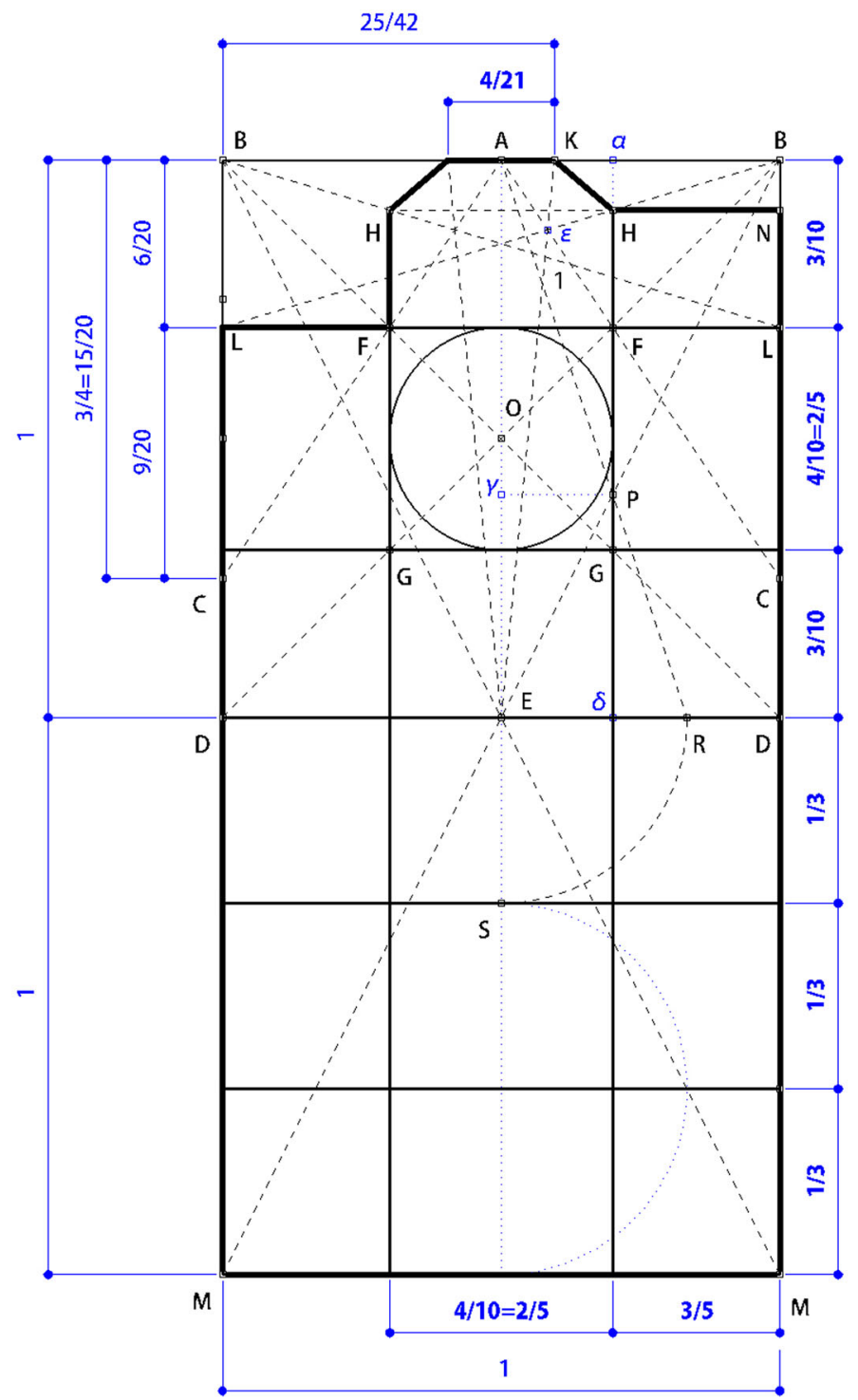

Fig. 5 Church with single aisles in fol. 13r of Compendio de arquitectura y simetría de los templos, BNE, MSS/8884. Drawing by the authors

the crossing and aisles and depth of transepts"). The remainder of the side, $3 / 10$ of the width, is given to the depth of the transepts and the width of the aisles.

The sanctuary chamfers are constructed using a peculiar method: a line is drawn from the upper right corner of the auxiliary square, B, to the upper left corner of the transept, L, while another one is drawn from the midpoint $\mathrm{A}$ of the upper side of the auxiliary square, to point $\mathrm{C}$, on the right side of the auxiliary square. Then a line is 
drawn from the midpoint of the bottom side of the auxiliary square, E, through the intersection $\varepsilon$ of lines LB and AC. The intersection $\mathrm{K}$ of this line and the upper side of the auxiliary square gives a corner of the chamfered sanctuary or ochavo. The other corner is given by the intersection $\mathrm{H}$ of the presbytery wall with line LB.

The shortest way for us to compute the positions of the sanctuary corners is to write the equations of lines LB and AC and determine the coordinates of point $\varepsilon$. This allows us to write the equation of line $\mathrm{E} \varepsilon$; the coordinates of its intersection with the side of the enclosing square give a dimension of $4 / 21$ basic units for the flat side of the ochavo. The position of the other corner in the chamfer, $\mathrm{H}$, can be computed using the equation of line LB; the coordinates of its intersection with line $\mathrm{HF}$ are $(7 / 10,91 / 100)$. As we may expect, the length of the chamfer is irrational (see Appendix "Position of corners and length of chamfer in the sanctuary").

While the first bay of the nave is included in the first auxiliary square, the remaining three bays are part of another auxiliary square. The depth of each bay is determined, again, by an apparently capricious geometrical tracing, using the intersection $\mathrm{P}$ of line $\mathrm{BE}$ with the arcade. Then, a line is drawn from point $\mathrm{A}$ through point $\mathrm{P}$ until it meets the side of the enclosing square at point $\mathrm{R}$. Next, the distance between $\mathrm{E}$ and $\mathrm{R}$ is transferred to the axis of the church in order to determine the length of the second bay; the length of the third and fourth bays equals that of the second bay.

Taking into account that the rectangle $\gamma \mathrm{P} \delta \mathrm{E}$ is similar to ABDE, which is a halfsquare, and that both triangles $\mathrm{A} \gamma \mathrm{P}$ and $\mathrm{P} \delta \mathrm{R}$ are also similar, it is easy to prove that ER equals $1 / 3$ of the width of the church. This measure is rotated in order to compute the length of the second, third and fourth bays of the church. Thus, these three bays together exactly fill the second auxiliary square; there is no gap at the end of the church, in contrast with the preceding example (see Appendix "Length of the second, third and fourth bays of the church"). However, this neat result comes together with a surprise. The first bay, with a depth of $3 / 10(0.30)$ of the side of the auxiliary squares, is actually shorter than the second bay, with $1 / 3(0.33)$ of the side, in contrast with the solution of the preceding example. ${ }^{4}$

\section{The Single-Aisle Church in fols. 13v-14r of the Compendio}

Once again, the third temple in Chapter $\mathrm{V}$ is constructed through a geometrical procedure (Figs. 6, 7), which in this case involves rotating squares as in some schemes in the thirteenth-century portfolio of Villard de Honnecourt, drawn by a

\footnotetext{
${ }^{4}$ Chanfón (1991: 39-40) states correctly that the proportion between the nave and the aisles is $3 / 4 / 3$, that the general proportion of the enclosing rectangle is $1 / 2$ and that the proportion between the catheti of triangle AER is $1 / 3$, and that this allows dividing the square at the end of the nave in three equal bays. However, he also mentions that the enclosing rectangle of the sanctuary and the sacristy is "proporción multiplex super particularis, en este caso triple sesquitercia". In Chanfón's source, Juan de Arfe y Villafañe (1585: 17) "dupla sesquitercia" means two squares and a third part of a square, that is, 7/3. For consistency, "tripla sesquitercia", an expression not used by Arfe, should mean three squares and a third, that is, 10/3. Anyhow, the actual proportion of the enclosing rectangle of the sanctuary and the sacristy is $7 / 3$, which corresponds with "dupla sesquitercia" in Arfe. Further, Chanfón does not deal with the chamfers or the difference between the first and the following bays.
} 


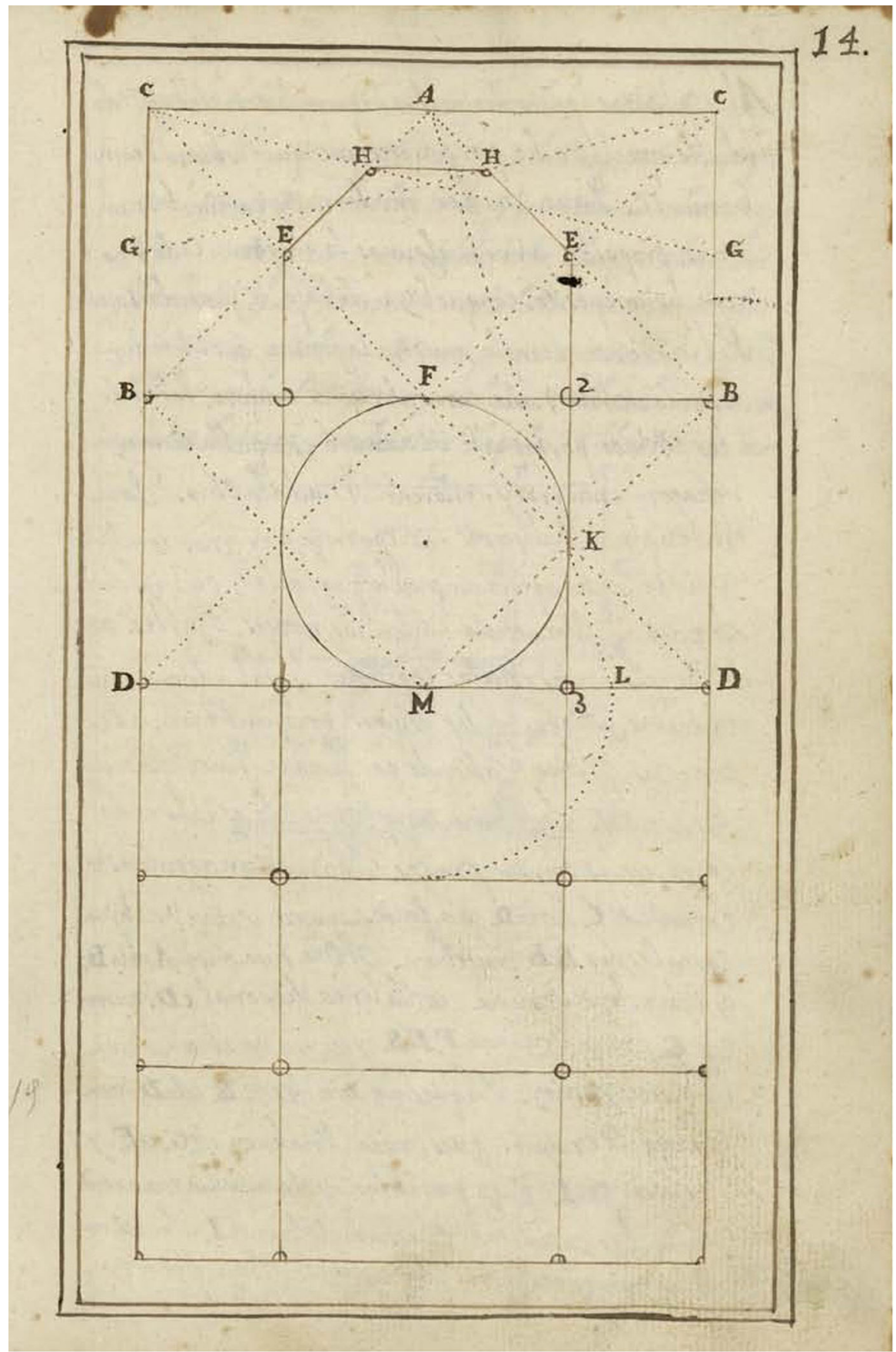

Fig. 6 Church with single aisles in fol. 14r of Compendio de arquitectura y simetría de los templos. Biblioteca Nacional de España, MSS/8884. The image is property of Biblioteca Nacional de España. Reproduced by permission 


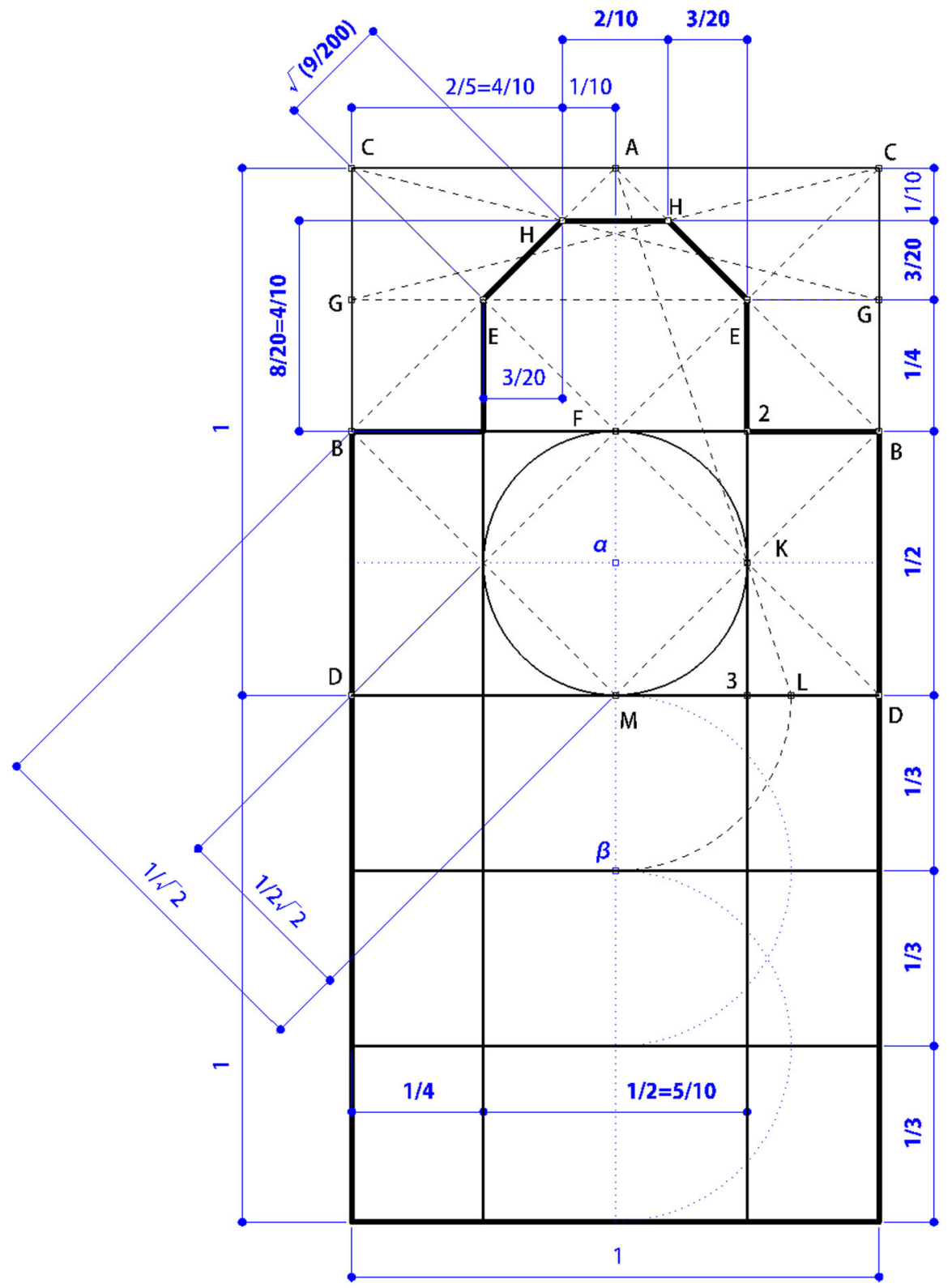

Fig. 7 Church with single aisles in fol. $14 \mathrm{r}$ of Compendio de arquitectura y simetría de los templos, BNE, MSS/8884. Drawing by the authors

Hand IV, (Honnecourt 2009: 19v, 20r; see also Barnes's study in the same volume, pp. 13, 127-129, 134-136), or the late fifteenth-century booklets of Mathes Roriczer (Shelby 1977: 85, 108, 109, 111). 
A first auxiliary square CCDD is drawn and then divided using the diagonals; their intersection divides the crossing from the sanctuary. A secondary set of diagonals is traced; its intersections, in turn, divide the nave and the aisles.

Although these geometrical constructions give incommensurable measures, these irrationals are not used for actual built members. Thus, the resulting forms feature simple arithmetical proportions as in the preceding examples. Of course, first-order diagonals divide the auxiliary square into halves, while second-order ones divide it into fourths. The edge of the crossing area equals $1 / 2$ of the auxiliary square or the width of the church. The transepts are defined by rectangles measuring $1 / 2$ by $1 / 4$ of the width of the church. The width of the nave measures $1 / 2$ of the width of the temple, while the aisles equal $1 / 4$.

As in the preceding example, the depth of the second, third and fourth bays, which lie outside this first auxiliary square, is computed using a geometrical construction carried out inside the first auxiliary square. A line is drawn, starting from point $\mathrm{A}$ and passing through the intersection of the second-order diagonal $\mathrm{MB}$ and the arcade; where this line meets the edge of the auxiliary square, DD, a point $\mathrm{L}$ is marked. Then, the distance ML is rotated in order to compute the depth of the first bay of the nave; the second and third bays should equal the second one. It is quite easy to see that the proportion between the catheti of $\mathrm{A} \alpha \mathrm{K}$ and AML is the same, namely $1 / 3$, so ML equals $1 / 3$ of side of the enclosing square, that is, $1 / 3$ of the width of the church. This dimension gives the depth of the nave bays; once again, they fit neatly inside a second auxiliary square.

One of these second-order diagonals, BA, is used together with the line CG in order to place points $\mathrm{H}$ and $\mathrm{H}$, which give the position of the corners of the chamfered sanctuary. As in the preceding example, the position of these corners may be computed writing the equations of lines GC and EA (see Appendix "The Single-Aisle Church in fols. 13v-14r of the Compendio. Position of the corners and length of chamfer in the sanctuary"). As expected, the length of the chamfer is irrational, measuring $\sqrt{ }(9 / 200)$. Thus, except for the sanctuary chamfers, the proportions are simple arithmetical, even musical ones. The ratio of width to depth of the nave bays is $2 / 3$, that is, sesquialtera, a perfect fifth; the shape of the crossings is a double square; even the enclosing rectangle of the sanctuary is $8 / 10$, or $4 / 5.5$

\section{The Church with Side Chapels in fols. $14 \mathrm{v}-15 \mathrm{r}$ of the Compendio}

Similar solutions, with one important exception, are used in the last temple in Chapter V (Figs. 8, 9).

Again, the crossing and sanctuary are enclosed in an auxiliary square that is divided three times using diagonals; their intersection points give the position of the corners of the transepts and the chamfers in the sanctuary, and indirectly, the crossing, the single nave, and the typically Iberian side chapels, known as capillas

\footnotetext{
5 Chanfón [1979 (1991), 40] states correctly that the proportion of the widths of the nave and aisles are $1 / 2 / 1$, and that the nave is divided into three equal bays. Once again, he does not deal with the sanctuary chamfers or lines $\mathrm{CG}$ and $\mathrm{AB}$.
} 


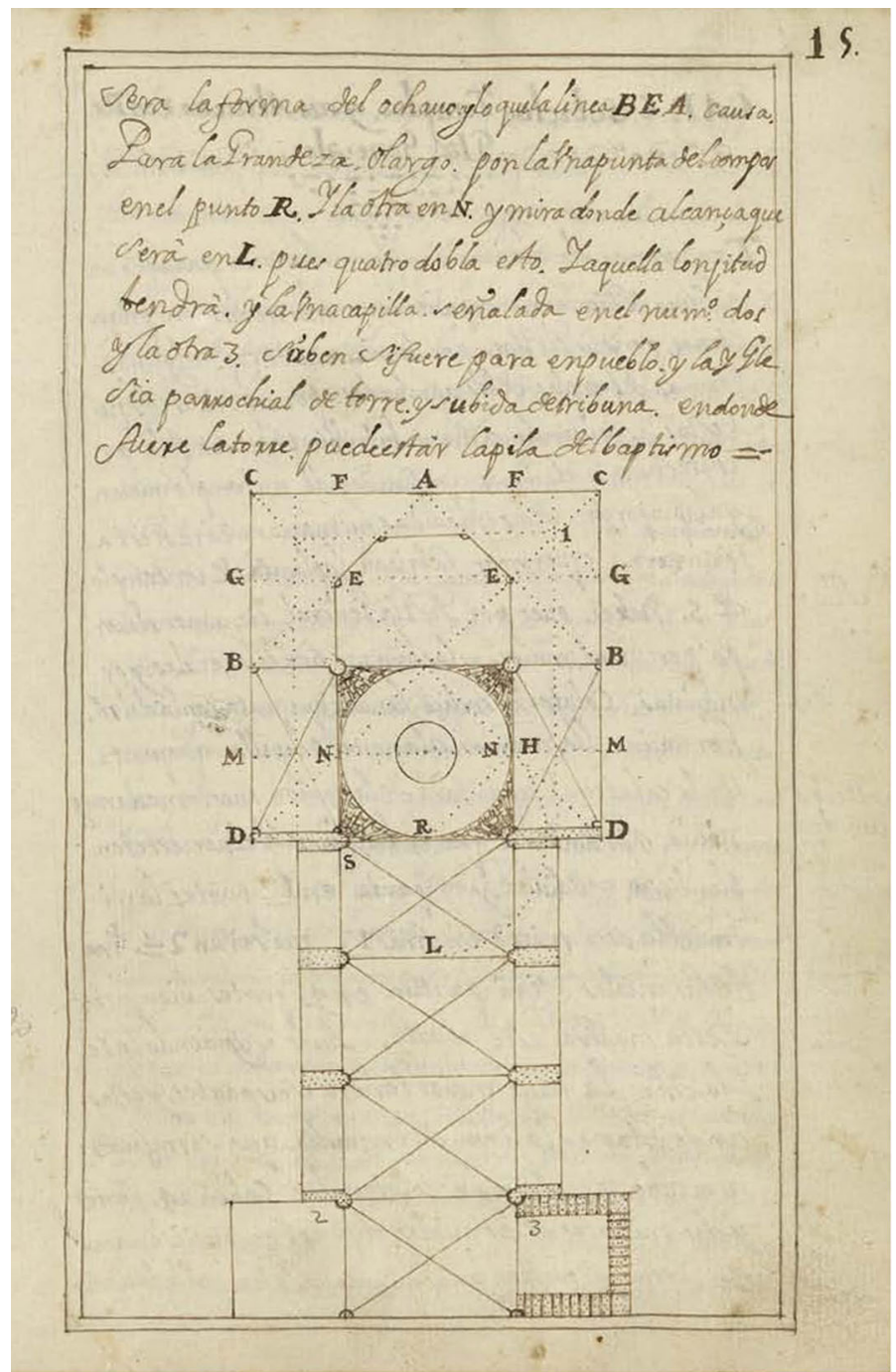

Fig. 8 Church with side chapels in fol. 15r of Compendio de arquitectura y simetría de los templos. Biblioteca Nacional de España, MSS/8884. The image is property of Biblioteca Nacional de España. Reproduced by permission

hornacinas. The depth of the nave bays is computed using the length of one of these diagonals.

As for the crossing, transepts and sanctuary, in spite of the Gothic character of the tracing method, the fact is that the diagonals divide the auxiliary square into halves, fourths and eights, and the actual lengths of the diagonals are not used, except for the sanctuary chamfers. Thus, the side of the square crossing measures $1 / 2$ of the auxiliary square, the depth of the transepts equals $1 / 4$ of this basic unit, the depth of the chamfered portion of the sanctuary measures $1 / 8$, and so on. 


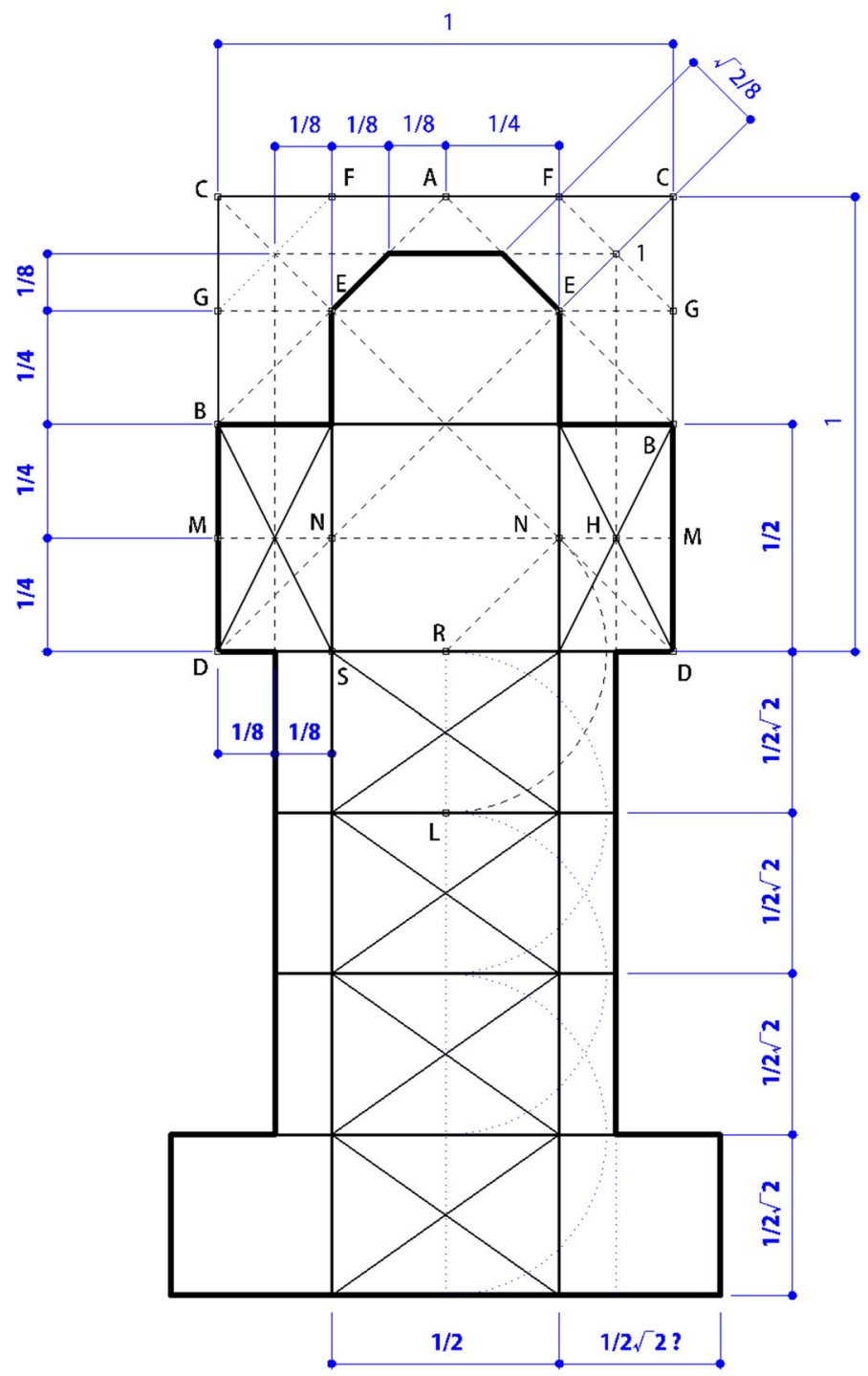

Fig. 9 Church with side chapels in fol. $15 \mathrm{r}$ of Compendio de arquitectura y simetría de los templos, BNE, MSS/8884. Drawing by the authors

These rational, arithmetical measures are used also for the width of the nave and the side chapels, which equal $1 / 2$ and $1 / 8$ of the auxiliary square. However, when computing the depth of the nave bays, the author of the Compendio rotates a secondorder diagonal, RN and brings it to the axis of the church. Of course, the result of such operation is an irrational, incommensurable proportion between width and 
depth of the nave, namely $1 / \sqrt{ } 2$ of the basic unit, while the proportion of the side chapels is $\sqrt{ } 2$ divided by four. ${ }^{6}$

It is evident, when seeing the whole ensemble of the church, that the nave does not fit into a second auxiliary square, nor does the church fit into a double square, as in the preceding examples. The proportion system of the church is therefore inconsistent. What is startling is that this could have been quite easily avoided, by making, for example, the depth of the nave bays equal to the combined width of half the nave and the depth of the side chapels, which equals $1 / 4$ plus $1 / 8$, that is, $3 / 8$ of the basic unit. This dimension equals 0.375 in decimal notation, while the depth of the nave bays, as constructed in the Compendio, is $1 /(2 \sqrt{ } 2)$, that is, 0.35355 , or $6 \%$ shorter; the difference would have been barely noticeable in practice. ${ }^{7}$

We can thus surmise that the author of the Compendio is completely indifferent to the notions of geometrical or arithmetical proportion, commensurability or inconmensurability. He uses a geometrical layout method that usually furnishes commensurable dimensions, but he does not eschew irrational proportions where they are brought about by geometrical logic - in particular, in sanctuary chamfersor when he chooses them out of whimsy or, what seems more likely, out of his unawareness of the notion of commensurable proportions.

\section{Conclusion: Graphical Rather than Geometrical}

These examples should caution us against thinking in terms of a simplistic opposition between the arithmetical, rational, commensurable proportional systems of the Renaissance and the geometrical, irrational, incommensurable results of the tracing methods of the Middle Ages. The proportioning system described in Chapter V of the Compendio leads to three different situations. In most cases, simple, arithmetical proportions arise from two different mechanisms. In the double-aisle church and the single-aisle church on fols. 12v-13r, similar triangles

\footnotetext{
6 See Appendix "The Church with Side Chapels in fols. 14v-15r of the Compendio. Proportion of the side chapels". The last chapel in the nave is used as the foundation of a bell-tower. The plan of the tower seems to be square, although the author of the Compendio does not say that in so many words; in that case, the side of the bell tower would be $1 / 2 \sqrt{ } 2$ times the reference unit. Chanfón ([1979] 1991, 40) explains correctly that the depth of the sanctuary and the chapels equals $1 / 8$ of the enclosing square, while the depth of the nave bays equals half the diagonal of the "trazo de bisección". This expression seems to allude to a square whose side equals half the side of the enclosing square; in other words, the depth of the bays equals the diagonal of a square whose side is $1 / 4$ of the basic unit. However, Chanfón does not mention that this dimension leads to irrational proportions. He seems to take for granted that the whole manuscript, including the first six chapters, was written by Simón García, although he acknowledges the influence of Rodrigo Gil; that García is following the numerical proportioning systems explained by Juan de Arfe y Villafañe (1585: 16r-17v), which are reproduced in fols. 79r-80v of the manuscript; and that all proportions in Chapter VI of the manuscript are rational. Of course, if Chapter V of the Compendio was written by Rodrigo Gil, as posited by most scholars, he could not have consulted Arfe's treatise, since he died in 1577 .

7 In fact, the actual depths of the bays in the drawing in the Compendio do not exactly follow either the irrational solution described in the text, that is, $1 /(2 \sqrt{ } 2)$, or the rational solution we are hinting at, $3 / 8$ of the basic unit; it stands somewhere in between. Of course, this slight difference can be caused by paper stretching. However, this irrational solution does not seem to arise from a copying error in Simón García's part; as Chanfón ([1979] 1991, 37) pointed out, in other parts of the Compendio García (1681, $79 \mathrm{r}-80 \mathrm{v})$ follows the rational systems of Juan de Arfe $(1585,16 \mathrm{r}-17 \mathrm{v})$.
} 
foster simple proportions such as $4 / 5,5 / 6$ or $3 / 4$. The use of enclosing squares, even when they are not strictly necessary and may encumber the physical execution of the full-scale layout, may derive from medieval design methods. This is much clearer in the single-aisle church in fols. $13 \mathrm{v}-14 \mathrm{r}$ and the church with side chapels, where the enclosing square is divided into halves using diagonals, the smaller squares resulting from this division are divided again into fourths of the enclosing square, and so on. All this leads to proportions such as 1/2, 1/4 or 2/5.

In most occasions, the irrational dimensions arising from this network of rotating squares are not used in order to design actual built members. There are exceptions, however. In some cases, the traditional chamfered layout of sanctuaries leads to irrational proportions; it is worthwhile to remark that the proportions between the flat sections, parallel to the enclosing squares, and other members of the layout, are generally rational. Thus, the irrational proportions of the chamfered sections should be seen as an unavoidable consequence of the use of this traditional layout, not a deliberate choice.

It is quite revealing to compare these ochavos with the proportions of the crypt of the chapel of the palace of Charles V in Granada, which features an octagonal plan and is covered by a lunette vault. The proportion between the width of the lunette and the radius of the octagon is $3 / 5$, while the proportion between the depth and the width of the lunette is $1 / 2$. Up to this moment, everything is rational and precise. However, the geometry of such a Classical form as the octagon brings about irrational dimensions; its side equals $2 \sin (\pi / 8)$ times the radius of the octagon; as a result, the distance between a corner of the octagon and the starting point of the lunette is also an irrational. That is, the geometrical constraints of many figures, in particular the central plans that feature so prominently in Wittkower's study, conspire to re-introduce the irrational proportions that Renaissance artists intended to exclude.

However, the irrationals in both medieval ochavos and classical octagons arise from unavoidable geometrical constraints. In contrast, the irrational dimensions of the bays in the last church in Chapter V are perfectly avoidable, as we have shown. This raises a puzzling question: since Rodrigo Gil was using mostly simple, numerical proportions, why should he bother with geometrical constructions?

Sergio Sanabria (1984: 109) argued that such methods are "as convoluted a mode of thinking as reading the Tarot or casting a horoscope". It seems that Rodrigo Gil uses geometrical proportioning schemes following an established medieval tradition, for didactic and practical reasons; this also explains the use of geometrical methods by Serlio. Transferring — as opposed to reproducing — a reduced-scale drawing to a full-scale layout with the instruments of the period leads to errors of significant magnitude. Besides, it is not easy to divide a dimension into thirds or fifths, in particular when tracing at full scale on the ground. ${ }^{8}$ At the same time, it is essential to take into account that this tradition

\footnotetext{
8 The use of Thales' theorem to solve this problem was known to De L'Orme (1567: 38v-39v) and Fray Laurencio de San Nicolás (1639: 24v-25r), but neither of them seem comfortable with this method; it is quite telling that the author of the Compendio divides lengths into halves and fourths, and angles into halves, but does not venture in other division problems, at least in chapter V. At the same time, it must be acknowledged that it is quite difficult to implement the first scheme, which involves an enclosing square twice as large as the actual church, in a crowded urban setting (Sanabria 1984: 107-108). This suggests that geometrical methods were used following an established tradition, but their practical foundation was beginning to vanish in the mid-sixteenth century.
} 
adhered to neither that of classical abstract geometry, nor to the practical geometry tradition of the Middle Ages, which was rooted in learned geometry. It was rather a "constructive geometry" or "geometria fabrorum" (Shelby 1972: 409; Sanabria 1984: 39; Ruiz de la Rosa: 2005), based in an empiric use of rulers and compasses, or better still, ropes, eschewing abstract concepts. Rodrigo Gil's proportional system may be aptly described as "graphical", rather than arithmetical or geometrical; he seems to have believed that the network of lines, drawn with pens or ropes, justifies in some way the proportions of any element of his churches, either rational or irrational. This explains his indifference to the notions of commensurability and incommensurability; paradoxically both Wittkower's and Von Simson's opposing stances are coherent with this graphical approach to proportion, since it furnishes both rational and irrational proportions.

\section{Appendix}

In this Appendix, we shall maintain the notation in the drawings of the Compendio, which uses both numbers and Latin letters. In order to avoid confusion with actual numbers, the numbers used in the Compendio as notation will be followed by a prime symbol ('); a few points that do not carry notation in the Compendio will be marked with Greek letters.

\section{The Double-Aisle Church in fols. $11 \mathrm{v}-12 \mathrm{v}$ of the Compendio}

In this section, we shall take the length $\mathrm{AC}$ of the side of the enclosing square in Fig. 3 as a basic reference unit, U.

\section{Depth of the Shallow Rectangle Added to the Presbytery}

In order to compute the depth of the shallow rectangle, $\mathrm{T} \varepsilon$, we should take into account that $\mathrm{C}^{\prime}$ is the diagonal of a square, and thus

$$
5^{\prime} \mathrm{F}=\mathrm{CF}=\mathrm{B} \varepsilon ; \quad 5^{\prime} \varepsilon=\mathrm{BC}-5^{\prime} \mathrm{F} ; 5^{\prime} \varepsilon=\mathrm{BC}-\mathrm{B} \varepsilon .
$$

Further, since triangles $5^{\prime} \varepsilon \mathrm{B}$ and $\mathrm{R} \gamma \mathrm{B}$ are similar,

$$
\begin{gathered}
\frac{5^{\prime} \varepsilon}{\mathrm{B} \varepsilon}=\frac{\mathrm{R} \gamma}{\mathrm{B} \gamma}=2 / 3 \\
\frac{\mathrm{BC}-\mathrm{B} \varepsilon}{\mathrm{B} \varepsilon}=\frac{5^{\prime} \varepsilon}{\mathrm{B} \varepsilon}=\frac{2}{3} ; \mathrm{BC}-\mathrm{B} \varepsilon=\frac{2}{3} \cdot \mathrm{B} \varepsilon ; \quad \mathrm{BC}=\frac{5}{3} \cdot \mathrm{B} \varepsilon \\
\mathrm{B} \varepsilon=\frac{3}{5} \cdot \mathrm{BC}=\frac{3}{5} \cdot \frac{1}{2} \cdot \mathrm{U}=\frac{3}{10} \cdot \mathrm{U} .
\end{gathered}
$$

Since point $\mathrm{D}$ divides $\mathrm{CN}$ into $1 / 4$ and $3 / 4$ and $\mathrm{BT}=\mathrm{CD}=1 / 4 \mathrm{U}$, 


$$
\mathrm{T} \varepsilon=\mathrm{B} \varepsilon-\mathrm{BT}=\left[\frac{3}{10}-\frac{1}{4}\right] \mathrm{U}=\frac{1}{20} \mathrm{U}
$$

\section{Depth of the Crossing}

The depth of the crossing, FH, can be computed taking into account that

$$
\mathrm{FH}=\mathrm{CH}-\mathrm{BE}=\mathrm{CH}-\mathrm{CF}=\mathrm{HS}-\mathrm{CF} .
$$

Now, HS is the combined length of NO, which equals $1 / 4$ of the reference unit, since $\mathrm{O}$ divides the side of the enclosing square into $1 / 4$ and $3 / 4$; plus $\mathrm{PO}$, the width of the second aisle, which measures $4 \mathrm{U} / 48$, as seen in the text; plus Y4, the width of the first aisle, which equals 5U/48, also seen in the text. Besides, CF equals $\mathrm{B} \varepsilon$, measuring 3U/10, as seen before. Thus, the depth of the crossing equals

$$
\begin{aligned}
\mathrm{FH}= & \mathrm{NO}+\mathrm{PO}+\mathrm{Y}^{\prime}-\mathrm{CF}=12 / 48 \mathrm{U}+4 / 48 \mathrm{U} \\
& +5 / 48 \mathrm{U}-3 / 10 \mathrm{U}=\left(\frac{21}{48}-\frac{3}{10}\right) \cdot \mathrm{U}=\frac{11}{80} \cdot \mathrm{U} .
\end{aligned}
$$

\section{Angular Dimensions in the Ambulatory}

Placing the origin of coordinates at point $\mathrm{T}$ and taking into account that BT equals $1 /$ $4 \mathrm{U}$ and $\mathrm{T} 4$ equals $8 / 48 \mathrm{U}$, and thus $\mathrm{BT}=3 / 2 \mathrm{~T} 4$, the equation of line $\mathrm{B} 4^{\prime}$ can be written as

$$
y=1 / 4-3 / 2 x,
$$

while taking into account that $\mathrm{T} 4=8 \mathrm{U} / 48=\mathrm{U} / 6$, the equation of the semicircular arcade between the outer and inner ambulatory can be expressed as

$$
x^{2}+y^{2}=1 / 36 \text {. }
$$

Substituting $y$ in the Eq. (2),

$$
\begin{aligned}
& x^{2}+\left(\frac{1}{4}-\frac{3}{2} x\right)^{2}=\frac{1}{36} ; \frac{13}{4} x^{2}-\frac{3}{4} x+\frac{5}{144}=0 \\
& x=\frac{\frac{3}{4} \pm \sqrt{\left(\frac{9}{16}\right)-\left(4 \cdot \frac{13}{4} \cdot \frac{5}{144}\right)}}{\frac{\frac{13}{2}}{4} \pm \sqrt{\frac{81-65}{144}}} \\
& =\frac{\frac{3}{4} \pm \sqrt{\frac{16}{144}}}{\frac{13}{2}}=\frac{\frac{3}{4} \pm \frac{4}{12}}{\frac{13}{2}}=\frac{\frac{3}{4} \pm \frac{1}{3}}{\frac{13}{2}}=\frac{\frac{3}{2} \pm \frac{2}{3}}{13}=\frac{9 \pm 4}{78} .
\end{aligned}
$$

The first solution of this equation,

$$
x=\frac{13}{78}=\frac{1}{6},
$$

corresponds to the abscissa of point $4^{\prime}$. The second solution 


$$
x=\frac{5}{78}
$$

gives the abscissa of point $8^{\prime}$. Substituting this value in the equation of line $\mathrm{B} 4^{\prime}$, the ordinate of point $8^{\prime}$ equals

$$
y=\frac{1}{4}-\frac{3}{2} \cdot \frac{5}{78}=\frac{1}{4}-\frac{5}{52}=\frac{2}{13} .
$$

The dimension of angle $8^{\prime} \mathrm{T} 4^{\prime}$ equals

$$
\operatorname{arctg}(2 / 13) /(5 / 78) \text {, }
$$

that is, 1.176 radians or $67^{\circ} 22^{\prime} 48^{\prime \prime}$.

\section{The Single-Aisle Church in fols. 12v-13r of the Compendio}

In this section, we shall take the length of the side of the square BBDD in Fig. 5 as a basic reference unit, $\mathrm{U}$.

\section{Width of the Crossing and Aisles and Depth of Transepts}

From Fig. 5, since BF is the diagonal of a square,

$$
\mathrm{BL}=\mathrm{B} \alpha=\mathrm{AB}-\mathrm{A} \alpha=1 / 2 \cdot \mathrm{U}-\mathrm{A} \alpha .
$$

Also, since triangles $\mathrm{A} \alpha \mathrm{F}$ and $\mathrm{ABC}$ are similar and $\mathrm{C}$ divides $\mathrm{BD}$ into $1 / 3$ and $2 /$ 3 ,

$$
\begin{gathered}
\frac{\mathrm{A} \alpha}{\mathrm{BL}}=\frac{\mathrm{A} \alpha}{\alpha \mathrm{F}}=\frac{\mathrm{AB}}{\mathrm{BC}}=2 / 3 \\
\mathrm{~A} \alpha=\frac{2}{3} \mathrm{BL}=\frac{2}{3} \mathrm{~B} \alpha=\frac{2}{3}\left(\frac{1}{2} \cdot \mathrm{U}-\mathrm{A} \alpha\right)=\frac{1}{3} \cdot \mathrm{U}-\frac{2}{3} \mathrm{~A} \alpha ; \\
\frac{5}{3} \mathrm{~A} \alpha=\frac{1}{3} \cdot \mathrm{U} ; \mathrm{A} \alpha=\frac{1}{5} \cdot \mathrm{U} .
\end{gathered}
$$

This dimension equals half the width of the crossing, so the full width of the crossing and the nave measures $2 / 5$ of the basic unit. As for the depth of the transepts, which equals the width of the aisles,

$$
\mathrm{B} \alpha=\frac{1}{2} \cdot \mathrm{U}-\frac{1}{5} \cdot \mathrm{U}=\frac{3}{10} \cdot \mathrm{U} .
$$

\section{Position of Corners and Length of Chamfer in the Sanctuary}

From Fig. 5, placing the origin of coordinates at the lower left corner D, the equation of line $\mathrm{LB}$, going from point $\mathrm{L}$ at the left side to $\mathrm{B}$ in the upper right corner, is 


$$
y=\frac{7}{10}+\frac{3}{10} x .
$$

The equation of line $\mathrm{AC}$, from $\mathrm{A}$ in the middle of the upper side to $\mathrm{C}$ on the right side, is,

$$
y=1-\frac{3}{2}\left[x-\frac{1}{2}\right]=1-\frac{3}{2} x+\frac{3}{4}=\frac{7}{4}-\frac{3}{2} x .
$$

The coordinates of point $\varepsilon$, at the intersection of both lines, must fulfill both equations.

$$
\begin{gathered}
\frac{7}{10}+\frac{3}{10} x=\frac{7}{4}-\frac{3}{2} x ;\left(\frac{3}{10}+\frac{3}{2}\right) x=\frac{7}{4}-\frac{7}{10} \\
\frac{9}{5} x=\frac{70-28}{40}=\frac{21}{20} ; x=\frac{21 \cdot 5}{20 \cdot 9}=\frac{7}{12}
\end{gathered}
$$

Substituting $x$ in Eq. (3),

$$
y=(7 / 10)+(3 / 10) \cdot(7 / 12)=(7 / 10)+(21 / 120)=7 / 8
$$

thus, the coordinates of $\varepsilon$ are $(7 / 12,7 / 8)$.

Using these coordinates, the equation of line $\mathrm{E} \varepsilon$ can be written as:

$$
y=\left[x-\frac{1}{2}\right] \cdot \frac{\frac{7}{8}}{\frac{1}{12}}=\frac{21}{2}(x-1 / 2) .
$$

The equation of line $\mathrm{BB}$ is $\mathrm{y}=1$. Thus,

$$
\frac{21}{2}\left[x-\frac{1}{2}\right]=1 ; x=\frac{2}{21}+\frac{1}{2}=\frac{25}{42},
$$

and the coordinates of $\mathrm{K}$ are $(25 / 42,1)$. Since the abscissa of $\mathrm{A}$ is $1 / 2$, which equals $21 / 42$, the distance between $\mathrm{A}$ and $\mathrm{K}$ is $4 / 42=2 / 21$; the dimension of the flat side of the ochavo is twice this distance, that is, 4/21.

As seen before in Eq. (3), the equation of line LB is

$$
y=7 / 10+3 / 10 x \text {. }
$$

The abscissa of point $\mathrm{H}$ equals $3 / 10+4 / 10=7 / 10$. Substituting this value,

$$
y=7 / 10+(3 / 10) \cdot(7 / 10)=7 / 10 \cdot 13 / 10=91 / 100 .
$$

Thus, the coordinates of point $\mathrm{H}$ are $(7 / 10,91 / 100)$. Taking this into account, the length of the chamfer equals

$$
\begin{gathered}
\sqrt{\left[\frac{7}{10}-\frac{25}{42}\right]^{2}+\left[1-\frac{91}{100}\right]^{2}}=\sqrt{\left[\frac{11}{105}\right]^{2}+\left[\frac{9}{100}\right]^{2}} \\
=\sqrt{\frac{121}{11025}+\frac{81}{10000}}=\sqrt{\frac{84121}{4410000}} .
\end{gathered}
$$




\section{Length of the second, third and fourth bays of the church}

In Fig. 5, both $\mathrm{E} \delta$ and $\mathrm{P} \gamma$ equal half the width of the nave, that is, 1/5 the basic unit, as seen in Sect. "Width of the crossing and aisles and depth of transepts". Besides, triangles $\mathrm{BDE}$ and $\mathrm{P} \delta \mathrm{E}$ are similar; thus

$$
\frac{\mathrm{P} \delta}{\mathrm{E} \delta}=\frac{\mathrm{BD}}{\mathrm{DE}}=2 ; \mathrm{P} \delta=2 \cdot \mathrm{E} \delta=2 / 5 \cdot \mathrm{U}
$$

Also,

$$
\mathrm{A} \gamma=\mathrm{U}-\mathrm{P} \delta=\mathrm{U}-\frac{2}{5} \cdot \mathrm{U}=\frac{3}{5} \cdot \mathrm{U}
$$

Further, since triangles $\mathrm{A} \gamma \mathrm{P}$ and $\mathrm{P} \delta \mathrm{R}$ are also similar,

$$
\frac{\mathrm{ER}}{\mathrm{AE}}=\frac{\gamma \mathrm{P}}{\mathrm{A} \gamma} ; \mathrm{ER}=\mathrm{U} \frac{\gamma \mathrm{P}}{\mathrm{A} \gamma}=\mathrm{U} \frac{\frac{1}{5} \mathrm{U}}{\frac{3}{5} \mathrm{U}}=\frac{1}{3} \mathrm{U} .
$$

This dimension is rotated in order to construct ES, the depth of the second bay of the church, and used also to lay out the third and fourth bays; thus, the combined depth of the second, third and fourth bays equals the reference unit, that is, BD, and the whole church is inscribed in a double square.

\section{The Single-Aisle Church in fols. 13v-14r of the Compendio: Position of the corners and length of chamfer in the sanctuary}

From Fig. 7, using the side of square CCDD as a reference unit and placing the origin of coordinates at point $\mathrm{C}$ at the upper left corner of the enclosing square, the equation of line $\mathrm{CH}$, from the upper left corner to point $\mathrm{G}$ in the right side, can be written as

$$
y=-1 / 4 x,
$$

while the one for line BEA, from B in the left side to $\mathrm{A}$ in the upper side is

$$
y=x-1 / 2 .
$$

Setting the two equations equal to each other,

$$
\begin{aligned}
& -\frac{1}{4} x=x-\frac{1}{2} ; \frac{5}{4} x=\frac{1}{2} ; x=\frac{1}{2} \cdot \frac{4}{5}=\frac{2}{5} ; \\
& y=-\frac{1}{4} x=-\frac{1}{10}
\end{aligned}
$$

Thus, the coordinates of $\mathrm{H}$ are $(2 / 5,-1 / 10)$. The length of the flat section of the sanctuary equals

$$
2 \cdot\left[\frac{1}{2}-\frac{2}{5}\right] \cdot \mathrm{U}=\frac{1}{5} \cdot \mathrm{U}
$$

while the length of the chamfer equals 


$$
\sqrt{\left(\frac{3}{20}\right)^{2}+\left(\frac{3}{20}\right)^{2}}=\sqrt{\frac{9}{200}} \cdot \mathrm{U} .
$$

\section{The Church with Side Chapels in fols. 14v-15r of the Compendio. Proportion of the side chapels}

From Fig. 9, taking as reference unit $\mathrm{U}$ the side of the square CCDD, the front of each side chapel measures $1 / 2 \sqrt{ } 2$ of the basic unit, as seen in the text, while the depth of the chapel is $1 / 8$ of the reference unit; thus, the proportion of the chapel is

$$
\frac{1 / 8}{1 / 2 \sqrt{2}}=\frac{2 \sqrt{2}}{8}=\frac{\sqrt{2}}{4} \text {. }
$$

Acknowledgements This study is a result of the research project 19361/PI/14 "Arquitectura pétrea y construcción renacentista en el sur de España", funded by a grant of the Fundación Séneca-Agencia Regional de Ciencia y Tecnología de la Región de Murcia in the frame of PCTIRM 2011-2014.

\section{References}

Arfe y Villafañe, Juan de. 1585. De Varia Conmensuración para la Esculptura y Architectura. Sevilla: Andrea Pescioni y Juan de León.

Bonet Correa, Antonio. 1991. Simón García, tratadista de arquitectura (1979). In Simón García, Compendio de arquitectura y simetria de los templos, 13-18. Valladolid: Colegio Oficial de Arquitectos en Valladolid

Camón Aznar, José María. 1941. La intervención de Rodrigo Gil en el manuscrito de Simón García. Archivo Español de Arte 14 (45): 300-305.

Casaseca Casaseca, Antonio. 1988. Rodrigo Gil de Hontañón (Rascafría, 1500 - Segovia, 1577). Valladolid: Junta de Castilla y León.

Chanfón Olmos, Carlos. 1991. Simón García y la proporción geométrica (1979). In Simón García, Compendio de Arquitectura y Simetría de los Templos, 31-42. Valladolid: Colegio Oficial de Arquitectos en Valladolid.

García, Simón. 1681. Compendio de arquitectura y simetría de los templos, conforme a la medida del cuerpo humano. Madrid: Biblioteca Nacional de España, Mss. 8884.

Gómez-Moreno, Manuel. 1949. El libro español de Arquitectura. Madrid: Instituto de España.

Hoag, John D. 1958. Rodrigo Gil de Hontañón: His work and writings. Late medieval and Renaissance architecture in Sixteenth century Spain. Ph.D. dissertation, Yale University.

Honnecourt, Villard de. 2009. The Portfolio of Villard de Honnecourt, A New Critical Edition and Color Facsimile, ed. Carl Barnes. Farnham: Ashgate.

L'Orme, Philibert de. 1567. Le premier tome de l'Architecture. Paris: Federic Morel.

Menéndez Pelayo, Marcelino. 1883-1889. Historia de las ideas estéticas en España. Madrid: Imprenta de A. Pérez Dubrull.

Rodríguez Méndez, Francisco Javier, Higinio Ramos Calle, and Jesús María García Gago. 2012. El canon de Simón García. Entre el rito y la geometría. In Actas del XI Congreso Internacional de Expresión Gráfica Aplicada a la Edificación, ed. Concepción López González, 426-433. Valencia: Universidad Politècnica de Valencia.

Ruiz de la Rosa, José Antonio. 2005. Fuentes para el estudio de la geometria fabrorum. Análisis de documentos. In Actas del Cuarto Congreso Nacional de Historia de la Construcción, ed. Santiago Huerta Fernández, 1001-1008. Madrid: Instituto Juan de Herrera.

Sanabria, Sergio Luis. 1982. The mechanization of design in the XVIth century: The structural formulae of Rodrigo Gil de Hontañón. Journal of the Society of Architectural Historians 41 (4):281-293. 
Sanabria, Sergio Luis. 1984. The evolution and late transformations of the Gothic mensuration system. Ph.D. dissertation, University of Princeton.

San Nicolás, Fray Laurencio de. 1639. Arte y uso de Arquitectura. s. 1. [Madrid?]: s. n. [Imprenta Real?]. Serlio, Sebastiano. 1545. Il primo libro d'architettura Paris: [impr. de I. Barbé].

Shelby, Lon R. 1972. The Geometrical Knowledge of Medieval Master Masons. Speculum 47 (3):395-421.

Shelby, Lon R., ed. 1977. Gothic Design Techniques: The Fifteenth-Century Design Booklets of Mathes Roriczer and Hans Schmuttermayer. Carbondale: Southern Illinois University Press.

Von Simson, Otto George. 1956. The Gothic Cathedral: Origins of Gothic Architecture and the Medieval concept of Order. New York: Pantheon Books.

Wittkower, Rudolf. 1949. Architectural Principles in the Age of Humanism. London: Warburg Institute.

José Calvo-López is an architect. His Ph.D. dissertation was awarded the Extraordinary Doctoral Prize of the Polytechnic University of Madrid in 2001. He teaches architectural history, construction history and other subjects at the School of Architecture and Building Engineering of the Polytechnic University of Cartagena, where he is now director of Doctoral program in Architecture. He has presented his research in seminars held by the Max-Planck Institute for the History of Science in Berlin, the Centre Alexandre Koyré (CNRS) in Paris, the Centre d'Études Superieures de la Renaissance in Tours (CNRS), Universitá di Palermo and the University of Minnesota, international conferences and peer-reviewed journals.

Macarena Salcedo-Galera is an architect since 2010. She joined the Polytechnic University of Cartagena as a research fellow in 2012, where she has specialized in architectural surveying and stereotomic analysis. Since then, she has been developing her Ph.D. dissertation Stone Construction in Renaissance Granada. In this area she has published her work in several articles in peer-reviewed journals and international conferences, such as Revista EGA-Expresión Gráfica Arquitectónica, Digital Heritage Conference or the 1st Hispanic Construction History Congress. In 2016, she has collaborated with the 3D Survey Group of the Polytechnic of Milan, working in the cathedral surveying project. 